\title{
Comparative profile of Communication Behaviour among the Rice growers in Imphal West District of Manipur, India
}

\author{
E. Ravi Goud* and Daya Ram \\ College of Agriculture, Central Agricultural University, Imphal-795004, Manipur, India \\ *Corresponding author
}

\section{A B S T R A C T}

Keywords

Information seeking behavior,

Information

processing

behavior,

Information out put

or sharing behavior

Article Info

Accepted:

18 April 2018

Available Online:

10 May 2018
A study was conducted in harongsabal block, imphal west district of Manipur with the objective of studying the relationship between selected socio-psychological profile and communication behaviour among the rice growers with a sample size of 120 rice growers. Ex post facto research design was followed. The results showed that, in imphal west district majority $(65.00 \%)$ of rice growers belonged to medium communication behaviour, 19.17 per cent of them belonged to low communication behaviour and 15.83 per cent of them belonged to high communication behaviour. Further correlation between sociopsychological profile and communication behaviour among the grower's results showed that, out of the twelve variables, education, size of landholding, socio-economic statues, extension contact, mass-media exposer, and sources of information showed a positive and significant association with communication behaviour of rice growers at one per cent level of significant. Other variable, like farming experience showed positive and significant association with communication behaviour of the rice growers at five per cent level of significant. Age, nature of family, annual income, risk preference and innovativeness showed non relationship with communication behaviour. So, Effective communication of scientific findings to millions of farmers is necessary for economic progress of the nation.

\section{Introduction}

Agriculture is the primary occupation of the people in most of the developing countries and it plays a vital role in the process of development. To enhance agricultural production, various communication sources are necessary. Communication is the process of exchanging/transmitting news, views, information, etc. and gain common understanding. Rice is one of the important food crops in the world and ranks second in terms of area and production. It is the staple food for about 50 per cent of the population in the world. It is planted on about 11 per cent of the total world's cultivated land. About 90 per cent world's rice is grown and consumed in Asian countries. Paddy (Oryza sativa L.) is one of the important cereal crops of India. It has the largest area in the world (43.86 million ha), with a total production of 104.80 million tonnes during 2014-15 and it stood next only to China in the world with respect to production. In Manipur, it is grown in both the hill and plain areas. Rice is the main crop accounting about 95 per cent of total food- 
grains production. Although the yield still exists lower than the all India productivity level $3380 \mathrm{~kg} / \mathrm{ha}$. It means there is a wide gap to be recovered by increasing the yield potential at farmer's field by adopting scientists recommended production technologies. The increase in productivity of rice will ensure food security of the region. Keeping this in view, the present study was taken up to study the Communication Behaviour among the Rice Growers in Imphal west district of Manipur.

\section{Materials and Methods}

The present study was conducted during the year 2016-17 by the following Ex-Post-Facto research design. The investigation was carried out in Imphal West District of Manipur selected purposively as it stands first in rice productivity. Out of two blocks (Wangoi and haorangsabal block) in the district, Haorangsabal block was selected purposively because majority of the farmers are paddy growers and paddy is main crop. And out of 24 GPs in haorangsabal block, only 3 GPs was selected randomly. From each selected GP, two villages were selected through using proportionate allocation random sampling method $(3 \times 2=6)$, total six villages were selected. From these six selected villages, 120 rice growers were selected through using proportionate allocation random sampling. The variables were quantified by taking the frequency and percentage of respondents falling under a given statement. The dependent variable communication behaviour of the rice growers are obtained by quantifying and then taking the frequency and percentage of response falling under the 3 components viz. information seeking behaviour, information processing behavior and information sharing or dissemination or output behavior. Communication behaviour was operationally defined as his expression of results from information seeking, information processing and information dissemination behavior (Sandhu, 1993).

\section{Results and Discussion}

\section{Communication behavior among the rice growers}

The main areas we focusing on the present study were assess the communication behaviour among the rice growers with the help of information seeking, information processing and information sharing behaviour.

\section{Information seeking behaviour}

It is clear that table 1 shows, those friends/relatives, progressive farmers and radio (with weight mean score values 2.29, 2.00, 1.94 respectively) plays an important role in information seeking behaviour among the rice growers in this study area. Possible reason might be that, they are frequent contact with them and they are more reliable and trust worthy persons when compare with other sources of information. These findings are line with the findings of Dambazau et al., (2015).

\section{Information processing behaviour}

Information processing behaviour of the rice growers we are estimated through the information storage behaviour and information evaluation behaviour. Findings were presented in Table 2 and 3.

Table 2 explain that rice growers store the received information by just knowing (2.20), by memorizing (1.71) and written in note book (1.58) were the most used methods. And followed by maintain of farm publications, newspaper clipping, and capturing a photograph with mean weight scores of 1.46 , 1.37 , and 0.87 respectively. And no one is using computer as a tool for storing the information. 
Table 3 revealed that for evaluating the received information the rice growers mostly discussed with friends/relatives (2.23), discussed with progressive farmers (1.75) and extension personal (1.40), followed by local leaders (1.30) and NGO's/SHG's (1.28). these findings are more or less similar with the findings of Dambazau et al., (2015).

\section{Information sharing behaviour}

Table 4 shows that the rice growers always disseminate the information at farm/home sharing with others and conveying to local members were the most used methods, and also very few rice growers disseminate through speaking in local meetings with mean weight scores $2.48,2.16$ and 1.24 respectively.

\section{Overall communication behavior among} the rice growers

The Table 5 shows that most of the rice growers were had $(75.00 \%)$ medium level of information seeking behaviour followed by low (16.67\%) and high (8.33\%) level information seeking behaviour. The possible reason could be that most of the respondents having medium extension contact, medium mass media exposer, medium sources of information. Hence, most of the growers falling under medium and high information seeking behaviour. These findings are line with the findings of Drulson (2011), Deepa (2016) and Atul et al., (2015).

Table 5 revealed that majority of the rice growers were $(72.50 \%)$ had medium level of overall information processing behaviour followed by low (15.00\%) and high $(12.50 \%)$ processing behaviour. This finding is line with the findings of Drulson (2011).

Table 5 revealed that the majority of the rice growers were $(86.67 \%)$ had medium level of information sharing behaviour, followed by low $(9.17 \%)$ and high (4.16\%). These findings are more or less similar with the findings of Drulson (2011) and Aparna et al., (2014).

Table 5 revealed that the majority of the rice growers were $(65.00 \%)$ had medium level of communication behaviour, followed by low $(19.17 \%)$ and high $(15.83 \%)$ communication behaviour among the rice growers.

Table.1 Distribution of the rice growers according to information seeking behavior

\begin{tabular}{|c|c|c|c|c|c|c|c|}
\hline & & & & & & & $=120$ \\
\hline Sl. No & Sources of information & & Exten & of utiliz & ion & & \\
\hline & & Always & $\begin{array}{l}\text { Some } \\
\text { times }\end{array}$ & Never & $\begin{array}{c}\text { Weight } \\
\text { score }\end{array}$ & WMS & Rank \\
\hline 1. & Radio & 50.00 & 33.33 & 16.67 & 233 & 1.94 & III \\
\hline 2. & T.V & 24.16 & 55.00 & 20.84 & 203 & 1.69 & VI \\
\hline 3. & News paper & 15.00 & 74.16 & 10.84 & 204 & 1.70 & V \\
\hline 4. & Extension agents & 18.33 & 36.67 & 45.00 & 173 & 1.44 & VII \\
\hline 5. & Friends/relatives & 79.16 & 16.67 & 4.17 & 275 & 2.29 & I \\
\hline 6. & Progressive farmers & 55.84 & 30.00 & 14.16 & 241 & 2.00 & II \\
\hline 7. & $\begin{array}{l}\text { Shopkeepers/input } \\
\text { dealers(fertilizer/pesticide } \\
\text { shops) }\end{array}$ & 35.00 & 36.67 & 28.33 & 206 & 1.71 & IV \\
\hline 8. & Farm magazines & 7.50 & 31.67 & 60.83 & 146 & 1.21 & IX \\
\hline 9. & Internet & 0.00 & 0.00 & 100 & 100 & 0.83 & $X$ \\
\hline 10. & SMS of KVKs & 9.16 & 51.67 & 39.17 & 170 & 1.41 & VIII \\
\hline
\end{tabular}


Table.2 Distribution of the rice growers according to information storage behavior

\begin{tabular}{|c|c|c|c|c|c|c|c|}
\hline \multirow{2}{*}{$\begin{array}{l}\text { Sl. } \\
\text { No }\end{array}$} & \multirow{2}{*}{$\begin{array}{c}\text { Sources of } \\
\text { information storage }\end{array}$} & \multicolumn{6}{|c|}{ Extent of utilization } \\
\hline & & Always & $\begin{array}{c}\text { Some } \\
\text { time }\end{array}$ & Never & $\begin{array}{l}\text { Weight } \\
\text { score }\end{array}$ & WMS & Rank \\
\hline 1. & By memorizing & 20.00 & 66.67 & 13.33 & 206 & 1.71 & II \\
\hline 2. & By written in note book & 15.00 & 61.67 & 21.67 & 190 & 1.58 & III \\
\hline 3. & $\begin{array}{l}\text { Keep information on } \\
\text { computer memory }\end{array}$ & 0.00 & 0.00 & 100.00 & 100 & 0.83 & VII \\
\hline 4. & Just knowing & 66.67 & 31.67 & 1.66 & 265 & 2.20 & I \\
\hline 5. & $\begin{array}{l}\text { Maintain farm } \\
\text { publications }\end{array}$ & 13.33 & 30.00 & 53.34 & 176 & 1.46 & IV \\
\hline 6. & Newspaper Clipping & 5.83 & 54.17 & 40.00 & 165 & 1.37 & V \\
\hline 7. & Captured photograph & 0.00 & 5.00 & 95.00 & 105 & 0.87 & VI \\
\hline
\end{tabular}

Table.3 Distribution of the rice growers according to information evaluation behavior

\begin{tabular}{|c|c|c|c|c|c|c|c|}
\hline \multirow{3}{*}{$\begin{array}{l}\text { Sl. } \\
\text { No }\end{array}$} & \multirow{3}{*}{$\begin{array}{l}\text { Sources of information } \\
\text { evaluation }\end{array}$} & \multirow{2}{*}{\multicolumn{4}{|c|}{ Extent of utilization }} & \multicolumn{2}{|c|}{$\mathrm{N}=120$} \\
\hline & & & & & & & \\
\hline & & Always & Some time & Never & Weight score & WMS & Rank \\
\hline 1. & $\begin{array}{l}\text { Discussed with } \\
\text { friends/relatives }\end{array}$ & 68.33 & 31.67 & 0.00 & 268 & 2.23 & I \\
\hline 2. & $\begin{array}{l}\text { Discussed with extension } \\
\text { personnel }\end{array}$ & 6.67 & 55.00 & 38.33 & 168 & 1.40 & III \\
\hline 3. & $\begin{array}{l}\text { Discussed with } \\
\text { progressive farmers }\end{array}$ & 20.00 & 71.67 & 8.33 & 211 & 1.75 & II \\
\hline 4. & $\begin{array}{l}\text { Discussed with local } \\
\text { leaders }\end{array}$ & 10.00 & 36.67 & 53.33 & 156 & 1.30 & IV \\
\hline 5. & $\begin{array}{l}\text { Discussed with } \\
\text { NGO's/SHG's }\end{array}$ & 6.66 & 41.66 & 51.67 & 154 & 1.28 & V \\
\hline
\end{tabular}

Table.4 Distribution of the rice growers according to their information sharing behavior

\begin{tabular}{|c|c|c|c|c|c|c|c|}
\hline \multirow{3}{*}{ Sl. No } & \multirow{3}{*}{ Sources of information sharing } & \multirow{2}{*}{\multicolumn{6}{|c|}{ Extent of utilization }} \\
\hline & & & & & & & \\
\hline & & Always & $\begin{array}{c}\text { Some } \\
\text { time }\end{array}$ & Never & $\begin{array}{l}\text { Weight } \\
\text { score }\end{array}$ & WMS & Rank \\
\hline 1. & Speaking in local meetings & 4.20 & 40.80 & 55.00 & 149 & 1.24 & III \\
\hline 2. & $\begin{array}{l}\text { Conveying to local } \\
\text { members/progressive farmers }\end{array}$ & 61.67 & 36.67 & 1.67 & 260 & 2.16 & II \\
\hline 3. & $\begin{array}{l}\text { At farm/home sharing } \\
\text { information to others }\end{array}$ & 98.33 & 1.67 & 0.00 & 298 & 2.48 & I \\
\hline 4. & By displaying of agric. Posters & 0.00 & 0.00 & 100 & 100 & 0.83 & IV \\
\hline 5. & $\begin{array}{l}\text { Writing article through agric. } \\
\text { Magazines }\end{array}$ & 0.00 & 0.00 & 100 & 100 & 0.83 & IV \\
\hline
\end{tabular}


Table.5 Distribution of the respondents according to overall communication behaviour among the rice growers

\begin{tabular}{|c|c|c|c|c|c|}
\hline $\begin{array}{l}\text { Sl. } \\
\text { No. }\end{array}$ & $\begin{array}{c}\text { Communication } \\
\text { Behaviour }\end{array}$ & Category & Frequency & Percentage & Mean \\
\hline \multirow[t]{3}{*}{1.} & \multirow[t]{3}{*}{ Information seeking } & Low & 20 & 16.67 & \multirow{3}{*}{20.34} \\
\hline & & Medium & 90 & 75.00 & \\
\hline & & High & 10 & 8.33 & \\
\hline \multirow[t]{3}{*}{2.} & \multirow{3}{*}{$\begin{array}{l}\text { Information } \\
\text { processing }\end{array}$} & low & 18 & 15.00 & \multirow{3}{*}{20.90} \\
\hline & & medium & 87 & 72.50 & \\
\hline & & high & 15 & 12.50 & \\
\hline \multirow[t]{3}{*}{3.} & \multirow[t]{3}{*}{ Information out put } & Low & 11 & 9.17 & \multirow{3}{*}{8.83} \\
\hline & & Medium & 104 & 86.67 & \\
\hline & & High & 5 & 4.16 & \\
\hline \multirow[t]{3}{*}{4.} & \multirow{3}{*}{$\begin{array}{l}\text { Communication } \\
\text { behaviour }\end{array}$} & Low & 23 & 19.17 & \multirow{3}{*}{50.14} \\
\hline & & Medium & 78 & 65.00 & \\
\hline & & High & 19 & 15.83 & \\
\hline
\end{tabular}

Table.6 Association of the socio-psychological profile among the rice growers with their communication behaviour

\begin{tabular}{|c|l|r|}
\hline $\begin{array}{c}\text { Variable } \\
\text { No }\end{array}$ & \multicolumn{1}{|c|}{ Variables } & $\begin{array}{c}\text { Correlation co-efficient value 'r' } \\
\text { value }\end{array}$ \\
\hline $\mathbf{1 .}$ & Age $\left(\mathrm{X}_{1}\right)$ & $0.096(\mathrm{NS})$ \\
\hline $\mathbf{2 .}$ & Education $\left(\mathrm{X}_{2}\right)$ & $0.364^{* *}$ \\
\hline $\mathbf{3 .}$ & Nature of family $\left(\mathrm{X}_{3}\right)$ & $-0.035(\mathrm{NS})$ \\
\hline $\mathbf{4 .}$ & Size of landholding $\left(\mathrm{X}_{4}\right)$ & $0.267^{* *}$ \\
\hline $\mathbf{5 .}$ & Farming experience $\left(\mathrm{X}_{5}\right)$ & $0.222^{*}$ \\
\hline $\mathbf{6 .}$ & Socio-economic status $\left(\mathrm{X}_{6}\right)$ & $0.336^{* *}$ \\
\hline $\mathbf{7 .}$ & Annual Income $\left(\mathrm{X}_{7}\right)$ & $0.133(\mathrm{NS})$ \\
\hline $\mathbf{8 .}$ & Extension contact $\left(\mathrm{X}_{8}\right)$ & $0.289^{* *}$ \\
\hline $\mathbf{9 .}$ & Mass-media exposure $\left(\mathrm{X}_{9}\right)$ & $0.489^{*}$ \\
\hline $\mathbf{1 0 .}$ & Risk preference $\left(\mathrm{X}_{10}\right)$ & $-0.051(\mathrm{NS})$ \\
\hline $\mathbf{1 1 .}$ & Innovativeness $\left(\mathrm{X}_{11}\right)$ & $-0.019(\mathrm{NS})$ \\
\hline $\mathbf{1 2 .}$ & Sources of information $\left(\mathrm{X}_{12}\right)$ & $0.454^{* *}$ \\
\hline
\end{tabular}

**correlation is significant at the 0.01 level of probability (2-tailed).

*correlation is significant at 0.05 level of probability (2-tailed).

NS- Non Significant. 
Table.7 Multiple-Lenoir regression analysis of independent variables with communication behaviour among the rice growers

\begin{tabular}{|c|l|c|c|c|}
\hline SI. No & \multicolumn{1}{|c|}{ Characteristics } & Beta & $\begin{array}{c}\text { Standard error } \\
(\mathbf{S . E})\end{array}$ & 't' value \\
\hline $\mathbf{1 .}$ & Age $\left(\mathrm{X}_{1}\right)$ & 0.138 & 0.758 & 1.343 \\
\hline $\mathbf{2 .}$ & Education $\left(\mathrm{X}_{2}\right)$ & 0.421 & 0.330 & $5.146^{* *}$ \\
\hline $\mathbf{3 .}$ & Nature of family $\left(\mathrm{X}_{3}\right)$ & -0.007 & 0.860 & -0.083 \\
\hline $\mathbf{4 .}$ & Size of landholding $\left(\mathrm{X}_{4}\right)$ & 0.148 & 0.381 & $2.049^{*}$ \\
\hline $\mathbf{5 .}$ & Farming experience $\left(\mathrm{X}_{5}\right)$ & 0.234 & 0.582 & $2.186^{*}$ \\
\hline $\mathbf{6 .}$ & Socio-economic status $\left(\mathrm{X}_{6}\right)$ & 0.068 & 0.065 & 0.750 \\
\hline $\mathbf{7 .}$ & Annual Income $\left(\mathrm{X}_{7}\right)$ & 0.010 & 0.655 & 0.126 \\
\hline $\mathbf{8 .}$ & Extension contact $\left(\mathrm{X}_{8}\right)$ & 0.314 & 0.270 & $4.206^{* *}$ \\
\hline $\mathbf{9 .}$ & Mass-media exposure $\left(\mathrm{X}_{9}\right)$ & 0.257 & 0.154 & $3.396^{* *}$ \\
\hline $\mathbf{1 0 .}$ & Risk preference $\left(\mathrm{X}_{10}\right)$ & -0.041 & 0.202 & -0.513 \\
\hline $\mathbf{1 1 .}$ & Innovativeness $\left(\mathrm{X}_{11}\right)$ & -0.018 & 0.332 & -0.272 \\
\hline $\mathbf{1 2 .}$ & Sources of information $\left(\mathrm{X}_{12}\right)$ & 0.302 & 0.214 & $3.939^{* *}$ \\
\hline **significant at 0.01 level of probability & $\mathrm{R}^{2}=0.571$ & $\mathrm{~F}=11.862$ & \\
\hline *significant at 0.05 level of probability & & & \\
\hline
\end{tabular}

The reason might be that, since most of the respondents have primary and middle school education, medium extension contact, medium mass-medium exposer and medium sources of information so it is quite natural to expect this kind of result. These results line with the results of Drulson (2011). The results in the table 6 exhibit that out of the twelve variables education, size of landholding, socio-economic status, extension contact, mass-media exposure, sources of information showed a positive and significant association with communication behaviour of rice growers at one per cent level of significant. Other variable, like nature of family, farming experience showed positive and significant association with communication behaviour of the rice growers at five per cent level of significant. This finding was support with the findings of Drulson (2011), Atul et al., (2015), Sundar and Manjit (2015), andPriyanka et al., (2016). Also risk preference and innovativeness has nothing to do with communication behavior of the growers these is because individual have free to seek, processed and share information regardless of the risk and innovativeness.

It can be concluded that majority of the rice growers in imphal west district had medium level of communication behaviour in relation to rice crop cultivation. The findings indicate that, still in this technological era also most of the growers getting information through friends and neighbours. The reason might be the functions of extension institutions like KVKs, ATMA, ATIC and other research stations are permitted in to a limited area may be due to inadequate transportation system and also lack of interest from the farmer's side too. Therefore, it may be concluded that there was a need to the policy makers and administrators should take care to design awareness programs regarding internet and 
agricultural based web sites and making easy accessibility of these sources at village level to make communication behaviour effective in this era.

\section{Acknowledgment}

The authors acknowledge the contributions of E. Ravi Goud, and Daya Ram. College of Agriculture, Central Agricultural University, Imphal, Manipur, India.

\section{References}

Aparna, R.K., Metal, S.K. and Goudapa, S.B. (2014). Information Management of Papaya growers of Karnataka. Indian Res. J. Ext. Educ., 14 (2): 31-35.

Atul, K.S., Singh, K.K and Raj, D.P. (2015). Information seeking behaviour of soybean growers. J. of com. Std., 33(2): 51-54.

Dambazau, S.A., Srivastava, J.P and Tajudeen, A. (2015). Communication Behaviour of Potato Growers in Allahabad district of Uttar Pradesh. J. of Com. Std., 33(2): 48-55.
Deepa, T. (2016). Assessment of training programs through perception of $\mathrm{KVK}$ trainees in imphal east district of Manipur. M.Sc. (Ag) Thesis, Department of Extension Education, COA, CAU, Imphal.

Drulson, R. (2011). A study on communication behaviour of potato growers in eastkhasi district of Meghalaya. M.Sc. $(\mathrm{Ag})$ thesis, Department of Extension Education, COA, CAU, Imphal.

Priyanka, K., Pankaj, O. and Satya, P. (2016). Communication pattern of Mushroom Growers. J. of Com. Std., 34(1): 69-75.

Sandhu, A.S. (1993). Text book on Agricultural communication process and methods. Oxford \& IBH publishing Co. Pvt. Ltd: 48-49.

Sreeram, V., S.V. Prasad. and T. Lakshmi. (2015). A Study on Entrepreneurial Behaviour of Kudumbashree, Neighbourhood Group (NHG) Members in Kerala. Indian Res. J. Ext. Educ., 15 (2): 123-126.

Sundar, B. and Manjit, S. (2015). Information Source Utilization Behaviour of BhutJolokia Growers in Upper Brahmaputra valley zone of Assam. $J$. Com. Std., 33(2): 56-61.

\section{How to cite this article:}

Ravi Goud, E. and Daya Ram. 2018. Comparative profile of Communication Behaviour among the Rice growers in Imphal West District of Manipur, India. Int.J.Curr.Microbiol.App.Sci. 7(05): 22732279. doi: https://doi.org/10.20546/ijcmas.2018.705.264 